\title{
Spatial Informatics in Water Supply Management: The Case of Mariborski Vodovod
}

\author{
Danilo Burnac, Bojan Erker, Simona Sternad Zabukovšek, \\ and Samo Bobek
}

\begin{abstract}
More and more companies in different industries realized benefits of GIS and its integration with business informatics. The chapter describes attempts on the area of GIS and business integration in public company for water supply in Maribor, Slovenia. The company Mariborski vodovod is the leader in using GIS in the region. Value-added which the company is achieving for GIS and business informatics integration is explained, and best practice is presented. The company already moved from the implementation of basic functionalities to more advanced functionalities. The case describes how such integration helps the company to run their daily operations better and how management is supported with a better and in-depth view on operations.
\end{abstract}

\section{Keywords}

Water supply management - Enterprise resource planning $\cdot$ ERP $\cdot$ Business

D. Burnac · B. Erker

Mariborski Vodovod, Public Limited Company, Maribor, Slovenia

e-mail: danilo.burnac@mb-vodovod.si;

bojan.erker@mb-vodovod.si

S. S. Zabukovšek $(\bowtie) \cdot$ S. Bobek

Faculty of Economics and Business, University of

Maribor, Maribor, Slovenia

e-mail: simona.sternad@um.si; samo.bobek@um.si intelligence $\cdot \mathrm{BI} \cdot$ Geographical information

systems · GIS · Water supply SCADA

\subsection{Introduction}

Mariborski vodovod is a public company located town Maribor in Slovenia. Maribor is the second biggest town in Slovenia and is a centre of its northeast region. The company is owned by municipalities in the region, and its main activity is the collection, purification and distribution of sufficient quantity and quality of drinking water for more than 166 thousand of customers - users - which is about $11 \%$ of the Slovenian population. They have the largest water distribution network in Slovenia. The distribution network consists of over $1615 \mathrm{~km}$ of water supply pipeline system and over 260 facilities. They operate ten water sources and some smaller reservoirs which provide the water to their customers. Annually they pump 13,7 million cubic meters of drinking water which supplies 16 municipalities. Their largest water source and pumping station is Vrbanski plato which provide 760 litres per second of fresh water. This location has natural as well as technical protection and is irreplaceable for supplying water.

Their complementary activities are manufacturing, servicing and sale of water meters, construction and assembly work on the water supply network, engineering projects and technical consultancy in the field of water supply. 
They are also issuing approvals for the project documentation and construction documentation. They are also carrying construction and building works for connecting customers to the public water supply network.

They are a public company, and as such, they operate as a non-profit organisation according to their mission of providing quality drinking water supply. Their strategy is to be a modern and efficient public company. One of their very important goals is to implement all aspects of the modern way of business including environmental friendliness and sustainability and also with a high level of social responsibility. In all business decisions, they include the environmental management issues in accordance with the principles of sustainable development. Their digital transformation orientation and implementation of e-business are focused in: more efficient core operations of water supply, nature prevention, user-friendliness to their customers, and improved connectivity with their stakeholders (owners and partners). With E-procurement in the online ordering processing, they implemented paperless procurement of materials and services. They have implemented e-invoicing so more, and more of their customers and partners are receiving e-invoices to pay them with a »single click «.

Their Facebook profile serves as very effective communication tools for forwarding relevant, upto-date information regarding water supply to customers and is also offering insight into their operational environment and activities. Their website is mainly used as a communication tool and a platform where the company information is published. Their web site also offers special services for blind people and for people with eye-difficulties providing them information about the latest news and also information about invoice details as voice messages.

They are one of the most successful public companies in Slovenia. They are recipients of the European certificate of business excellence; their annual report is the »Best Annual Report among other organisations in 2012 in Slovenia«. They are the first company to receive the award from the Slovenian Chamber of Communal
Economy. By receiving the Family-Friendly Company certificate, they proved that they follow the principle that a successful career and family life are not incompatible. Therefore they implement the solutions and activities to enable the coordination of work and family life of employees. They also received several Slovenian awards for social responsibility »HORUS $\ll$. Thus they have proved that they are aware of social responsibility regarding the environment, their employees, their business partners and general society.

They know how important it is to raise the awareness of citizens and the wider public about saving drinking water. Therefore they associate themselves with educational institutions and particularly for the younger generation. They prepare lectures about how to deal efficiently with drinking water and how important it is that the environment near water sources remains clean.

In the area where Mariborski vodovod supplies citizens with drinking water, they placed 33 outdoor drinking fountains where passers-by can refresh themselves on hot days with cold and tasty drinking water. Because animals need water too, we also added drinking fountains for pets to the same of the fountains.

Their drinking water supplies are under constant surveillance. Both, the internal and external microbiological and chemical analyses are carried out, which ensures that safe drinking water reaches the user's tap. With the careful selection of suppliers and installing quality materials, they try to ensure customers satisfaction. Of course, they also conduct regular maintenance of water supply facilities and the water supply network, and they are trying to raise awareness among the general public how to deal with drinking water efficiently.

\subsection{Information Systems Infrastructure and Architecture in Mariborski Vodovod}

Water supply is among the most important and crucial utilities delivered by countries. EU Directive 114/2008 defines water supply infrastructure 
as »critical infrastructure « of EU. Legislation in Slovenia follows these guidelines and further defines approaches and procedures regarding critical infrastructure operation and maintenance. This includes requisites for uninterrupted supply of healthy drinking water 365 days and $24 \mathrm{~h}$ daily.

Information infrastructure has crucial role In fulfilment of these requirements while the collection, purification and distribution of sufficient quantity and quality of drinking water is possible only in a highly digitalised environment. Information infrastructure implemented and information systems used are considered with the same importance as water supply network while they are integrated. They have to operate as crucial infrastructure all time, and they have to fulfil the requirements for information systems security and safety. Mariborski vodovod is using smart water network layered approach for intelligent management of their system (Fig. 12.1).

Majority of operations in the water supply are conducted outside in open-air space; therefore it is very important that information systems support space issues and enable the use of geolocation and spatial data. Information systems architecture in Mariborski vodovod comprise of three categories of information systems, applications and tools:

- Business information systems - comprised in its core of Enterprise resources planning

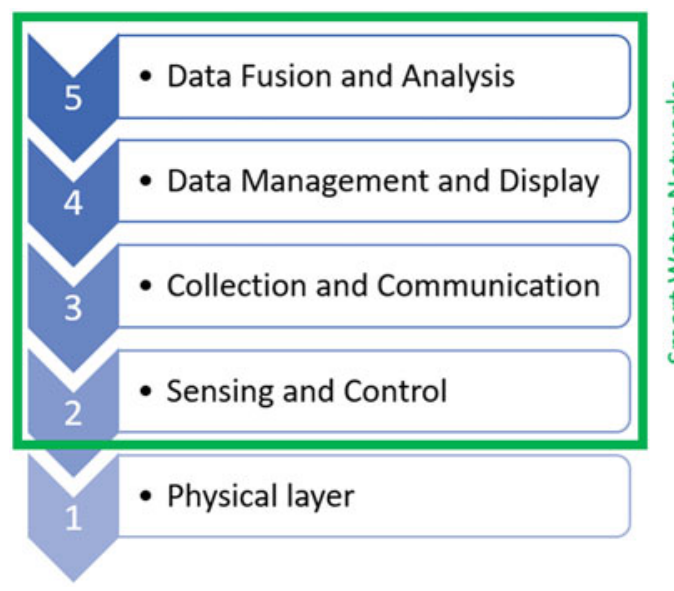

Fig. 12.1 Layers of smart water networks. (Source: Authors) solutions and other applications for support of business activities of the company

- Geo information systems (GIS) - includes access to cadastre of the territory on which Mariborski vodovod supplies water and applications and tools for processing of spatial data and their visualisation

- Technical (SCADA) information systems includes applications needed for monitoring and control of pumping and distribution system of water.

Key information systems in Mariborski vodovod are (Fig. 12.2): Enterprise resource planning applications, Asset management, Work order management, Customer information systems with billing, GIS, Water loss, Water quality, Control room. Information infrastructure of the company consists of a modern network of servers and workstations which allows running all necessary information systems/applications/tools also in a mobile environment.

\subsection{Integration of ERP and GIS}

Enterprise resource planning functionality is in Mariborski vodovod achieved by integration of accounting, warehouse management and human resources management application modules with billing, work order management, asset management, water loss management, smart meter reading, and vehicles management.

To implement necessary spatial features and functionalities needed for better quality of conducting their business activities - use of geo-visualisation of ERP data - they have implemented ArcGIS from ESRI. Employees in Mariborski vodovod perceive ArcGIS as a very user-friendly and easy-to-use application. With the integration of ERP functionality and GIS functionality, they added value to support for operational activities (Fig. 12.3) in the sense of enhanced support for employees.

Mariborski vodovod recently extended their ERP applications with DMS system including e-archive which improved accounting processes 
Fig. 12.2 Information systems architecture for integrated water network management. (Source: Authors)

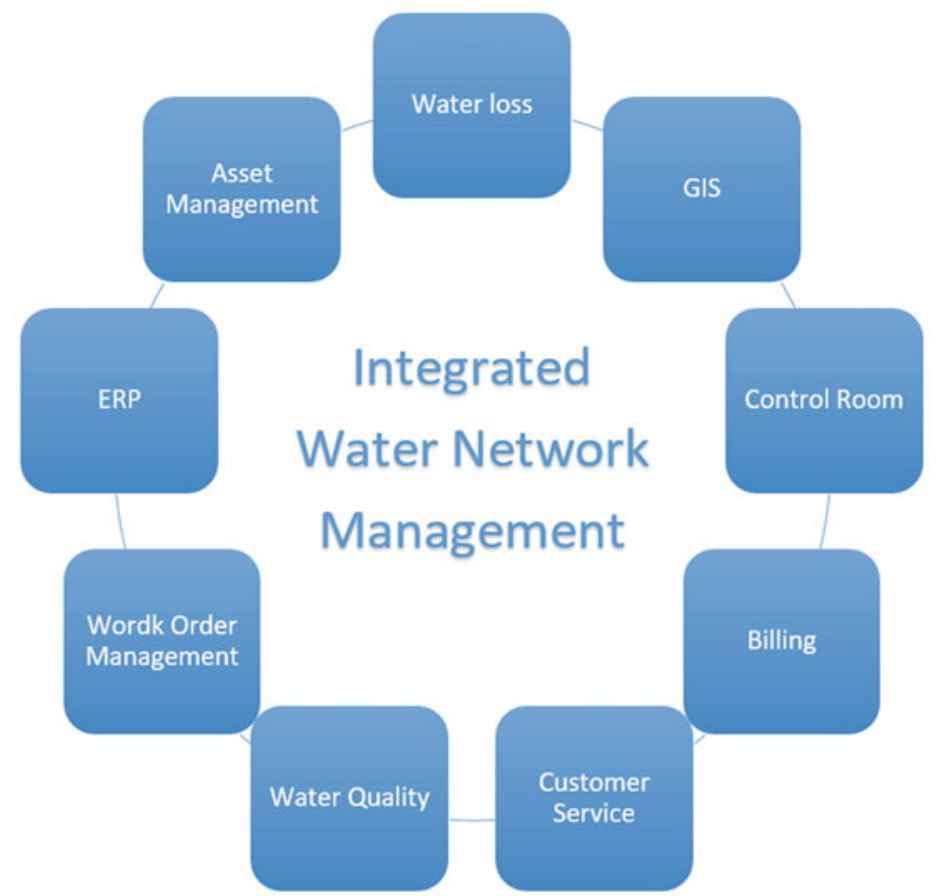

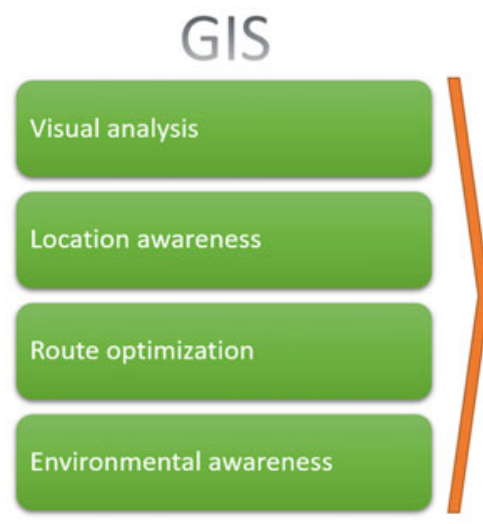

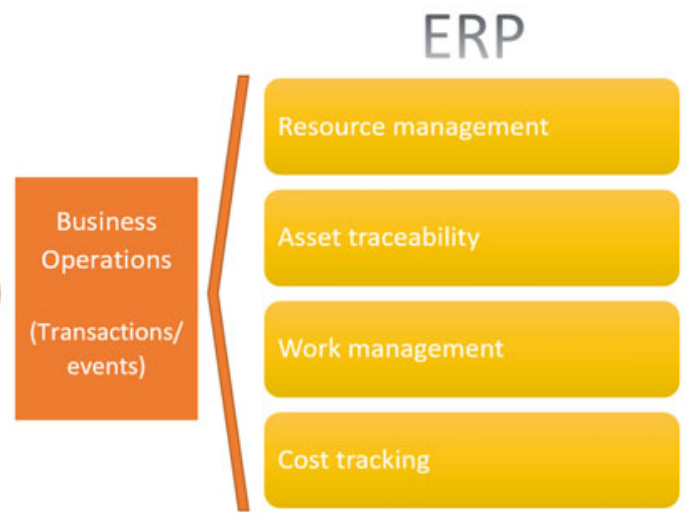

Fig. 12.3 Enhanced support for employees on an operational level with ERP and GIS integration. (Source: Authors)

and accessibility to the documents and their tracking. Currently, they are integrating the DMS system with GIS system to add spatial features. Report on Fig. 12.4 shows how working/route documents of employees assignments are linked with spatial data showing vehicle license plates showed on the map to allow better work force management. The data source for such reports are an ERP system and a DMS system.
Management data provided by reporting functionality of used ERP system and other BI tools are enhanced with spatial features to provide spatial dashboards for management. Dashboard on Fig. 12.5 shows employees efficiency for chosen month on the basis of the data obtained from smart meter reading software and information is visualised on the map. The map shows the number of smart water meter 


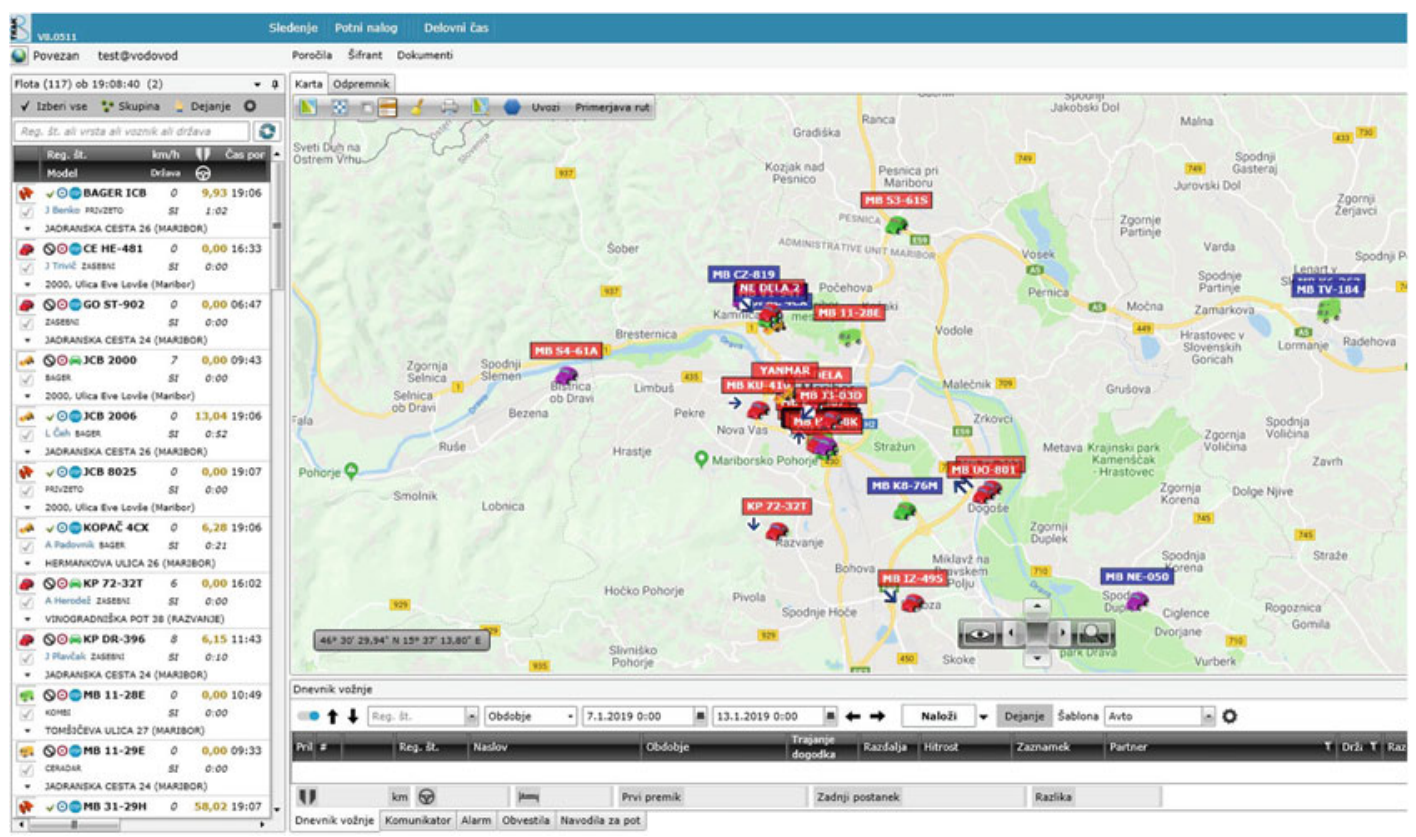

Fig. 12.4 Linking spatial data with the working/route documents of employees assignments with vehicle license plates showed on the map. (Source: Authors)

reads (remote reading). It enables zooming by which detail information about each water meter (reading date and time, volume, reading distance) can be seen.

\subsection{Integration of SCADA and GIS}

Technical information systems and applications SCADA - intended to manage water pumping and distribution to the customers. On the basis of the measurements of flow rates, pressures, surfaces of the water in containers that are part of the network system, SCADA maintains the correct pressure in the network, operates pumps in the pump stations and stations for drawing water, and if necessary, it doses needed quantities of disinfectant and ensures uninterrupted supply of drinking water. For the security reasons, this part of the information system is to some extent isolated from other parts of information systems. The maintenance of this part is essential, as in the case of operational difficulties it may lead to immediate disruptions of the water supply (Fig. 12.6).

\subsubsection{The Project “Ruptured Pipelines in the Network"}

The project was created to visualise locations of the ruptured pipelines in the network and to help the decision makers to decide where to invest and reconstruct water supply network. The basic idea of this project was to make a map of the water supply network that shows the points where the pipelines are broken. It allows detailed insight into the individual data on ruptures, and employees can search needed information by various criteria (time, types of materials, the reasons for a rupture, etc.) and insight into related repair costs. Employees can have a "statistical" view showing the number of events in the area, which is particularly suitable for decision makers. Increased number of ruptures in a smaller area indicates that they have to invest in a specific part of the network. Technology allows employees to have immediate insight into the current situation on the basis of real-time information (Figs. 12.7, 12.8 and 12.9).

The project "Ruptured pipelines in the network" enables better management of water supply network delivering following functionalities 


\section{Odčitovalno obdobje: 201901 Oracle MB v}
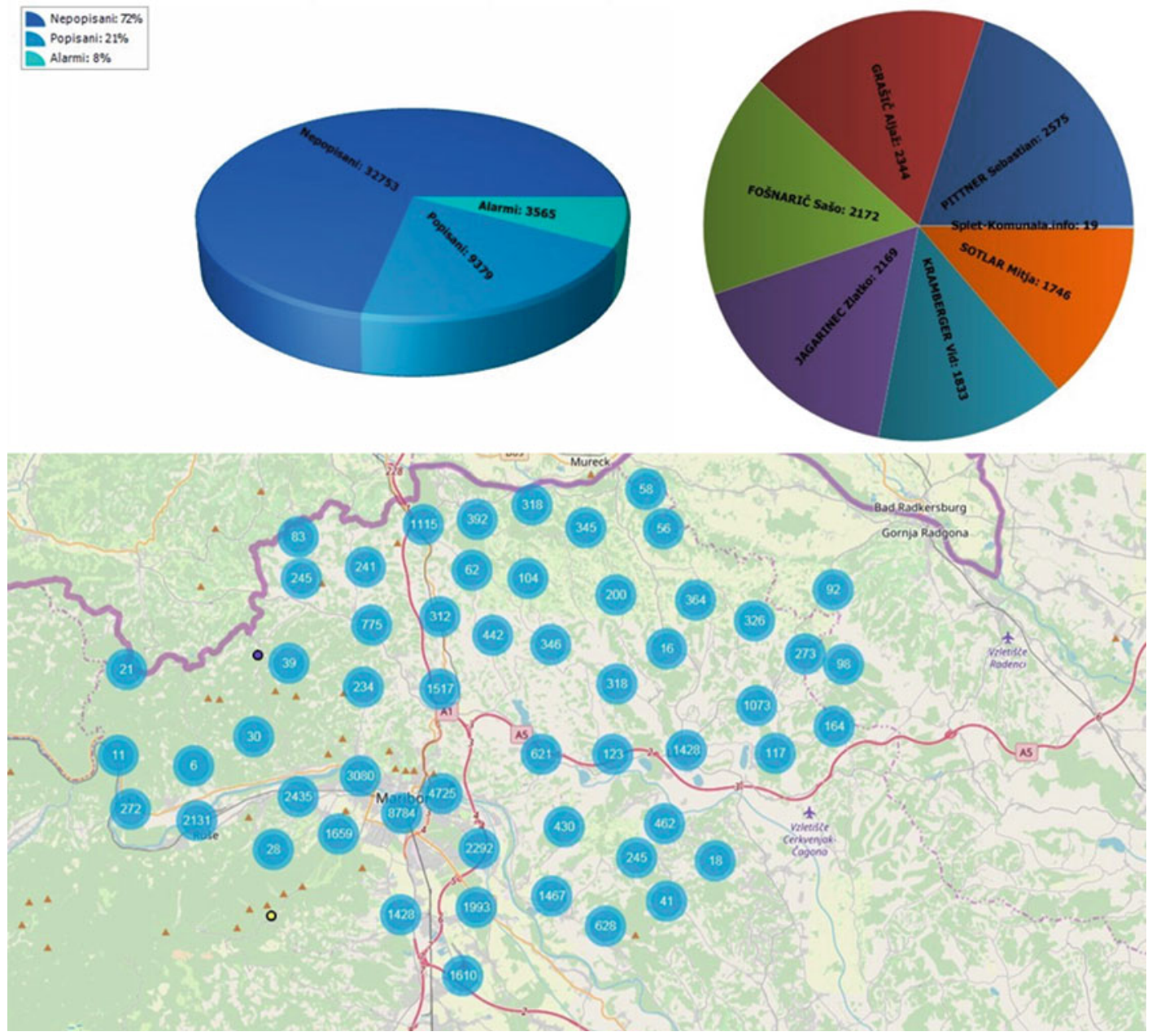

Fig. 12.5 Spatial dashboard is showing smart meter reading data analytics. (Source: Authors)

(Fig. 12.10): monitoring and alerts based on the remote control, reporting for decision making, feedback and automation, evidence-based planning.

\subsubsection{Project «Smart Metering and Pay-As-You-Use Billing“}

Modern concepts of services and utilities billing emphasise the »pay-as-you-use « models. In some industries such as electricity and telecommunications, this is quite easy because of technology platforms used. For water supply implementation of »pay-as-you-use « concept is more difficult while customers have mechanical water meters which are mechanical. For such devices, it is necessary that water supply company employee visits customer premises and reads the water meter and the data is edited to tablet. This is usually done once a year. During the year customers are billed on the basis of forecasted/ calculated use. The problem arises if there is substantial leaking of water for which customer is not aware while the customer gets a huge bill at the end of the period. 


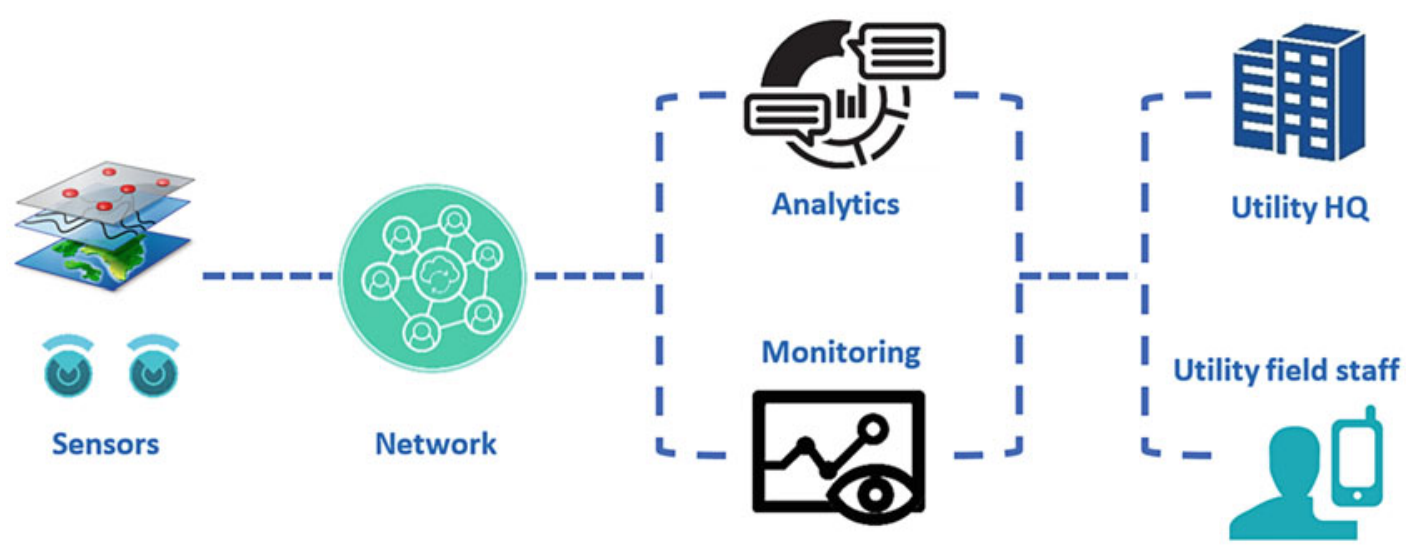

Fig. 12.6 Monitoring of water supply technical systems. (Source: Authors)

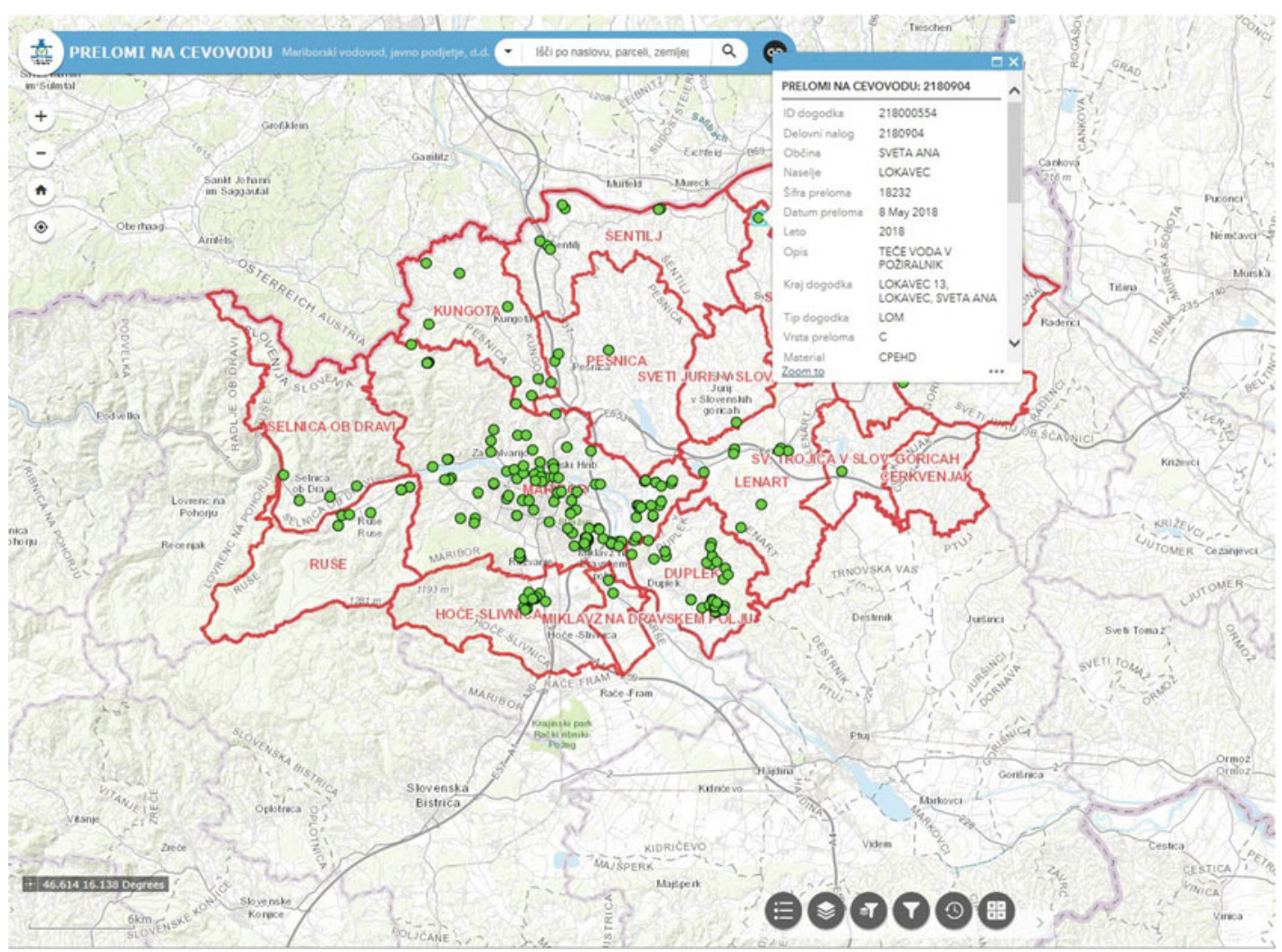

Fig. 12.7 Visualisation of the locations of ruptured pipelines in the specific period and detailed information about certain rupture. (Source: Authors)

Smart metering technology allows collecting of water consumption data in real time and from a distance up to $100 \mathrm{~m}$ without entering customer premises. They started a project in 2013 and 2018 $95 \%$ of customers have smart water meters. Data are collected by employees who are driving prescribed routes which allows that data is transmitted from smart meter to the device in the car (range is $100 \mathrm{~m}$ ) (Fig. 12.11). 


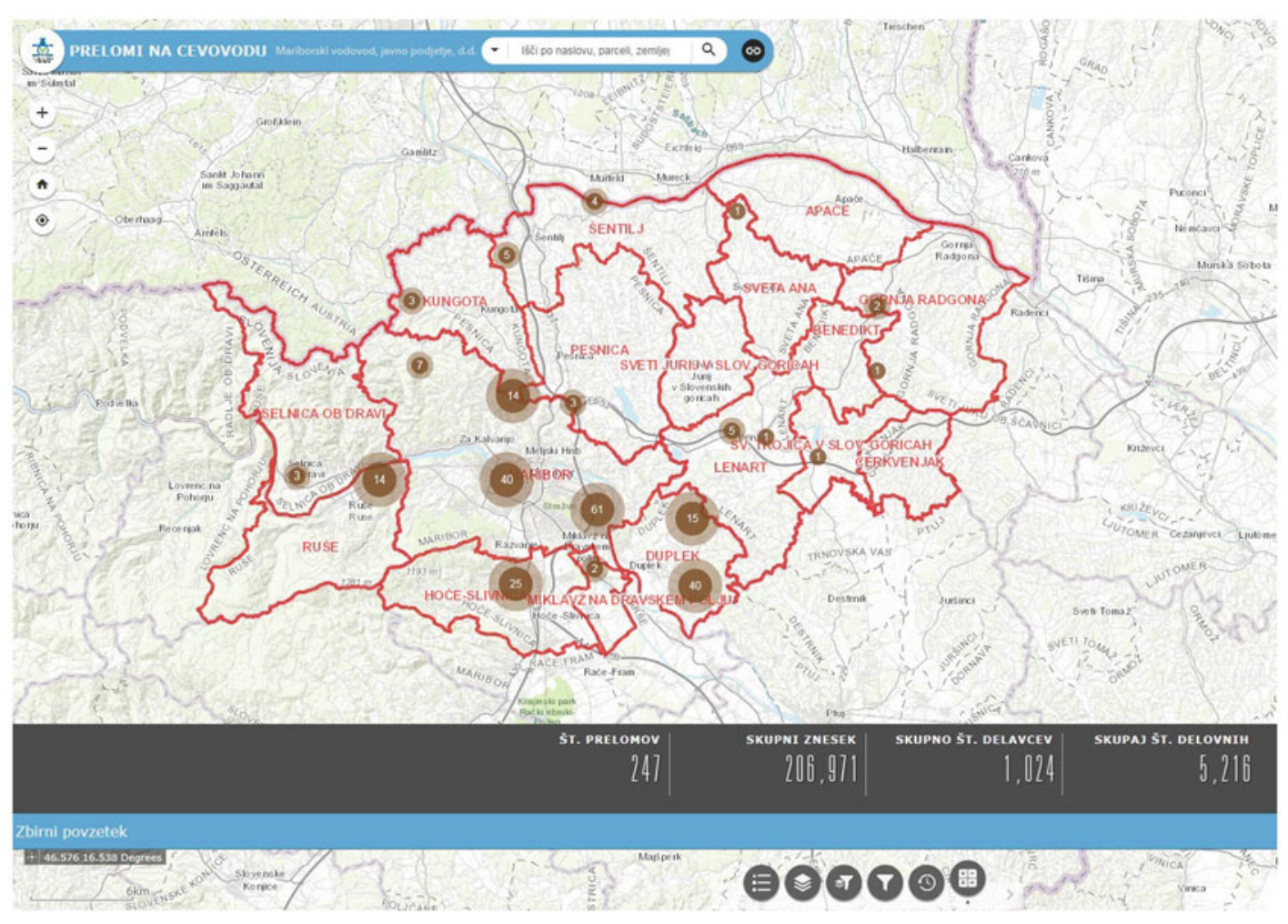

Fig. 12.8 Numerical (statistical) visualisation of pipeline ruptures events in the specific period and estimated repair costs. (Source: Authors)

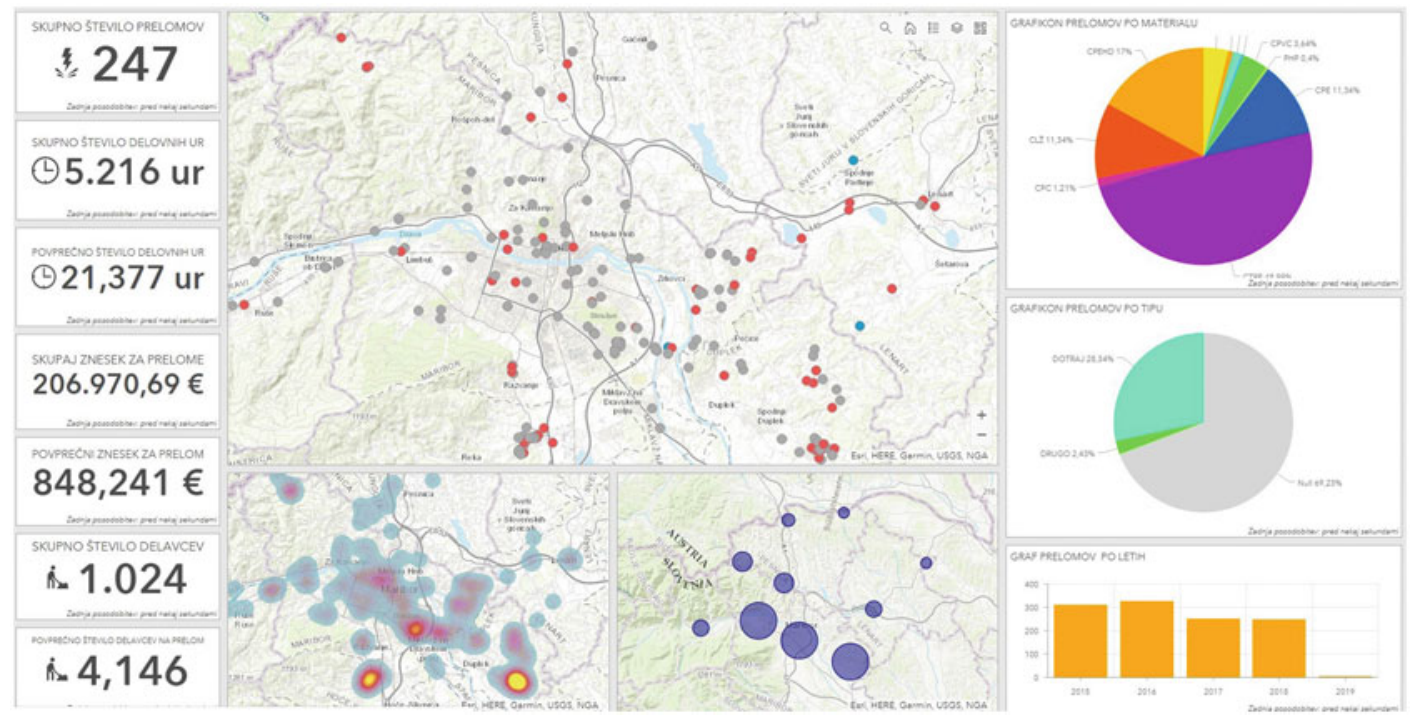

Fig. 12.9 Visualisation of the pipeline ruptures in the network in the form of a dashboard. (Source: Authors) 


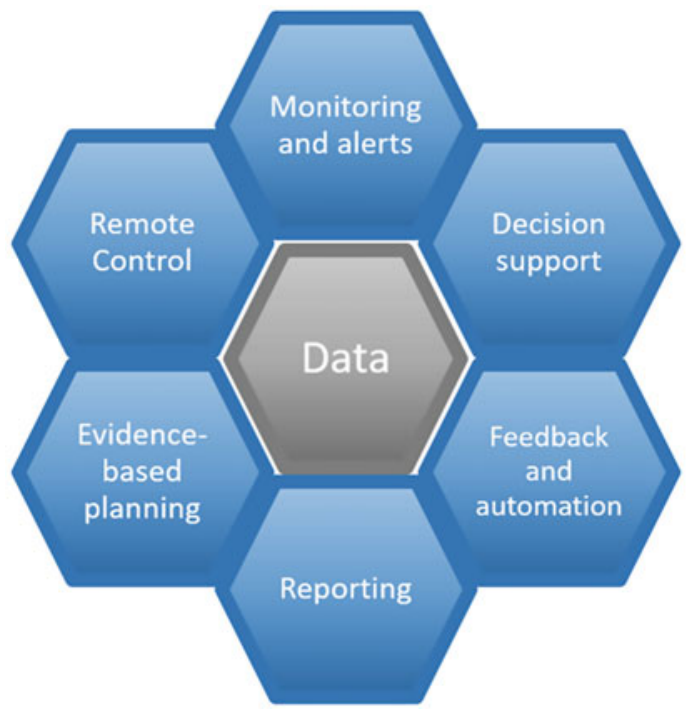

Fig. 12.10 Functionalities of spatial data enabled management. (Source: Authors)

\subsubsection{The Project "Pumping Facilities"}

Maintenance of the water supply infrastructure, which includes water reservoirs, pipeline network and associated facilities (pumping stations, stations for water drawing, water storages) is one of the basic activities of the company and essential condition for quality water supply. In order to gain a comprehensive overview of the situation on the water supply infrastructure, for the purposes of maintenance as well as for the municipalities who are owners of the company, they have drawn up a map of the network, which allows overview of all above-ground water supply facilities, display necessary data of a single facility, its maintenance status, photos and photos of the necessary maintenance operations. The map is also available on mobile devices and is an excellent help for maintainers and to employees in the company, who take care of the accounting records of the infrastructure. It is also useful in discussions with the municipalities who are owners on the necessary investments in the reconstruction (Fig. 12.12).

For the effective carrying out of communal services the information system must support spatial data display, mobile business, it must be easy to use, and it must support sharing of information to external users. Having data from the information system at disposal timely and at all times enables the company to carry out all services in a quality manner and thus maintains confidence and reputation to customers. Comprehensive water analytics is needed which allows: insight in usage and loss, information about conservation, indicators regarding operations and maintenance, safety and quality, asset management and efficiency, sourcing efficiency (Fig. 12.13).

\subsection{Integration of Advanced Applications and GIS}

Mariborski vodovod is conducting intensive digital transformation which was defined as part of their strategy. To achieve these goals they have already implemented some projects of advanced applications while some are still in progress. In several advanced applications, high level of integration with GIS is needed.

\subsubsection{Project "Water System Optimisation with Hydraulic Modelling"}

Pipeline network which comprises water systems of Mariborski vodovod measures more than $1600 \mathrm{~km}$. The way from the water source to the customer could be in some cases also more than $40 \mathrm{~km}$. For safe and reliable water supply detail insight in the system is necessary. The technology of hydraulic modelling of water systems allows a detail understanding of the system based on the cadastre data and measuring equipment build in the water system. This allows calculation of pressures and through flows which can be compared with measured data. Comparison can be used for different simulations regarding changes in water systems operation. With hydraulic model, it is possible to predict directions of water flows and how old is the water is certain parts of the water system. These allow 


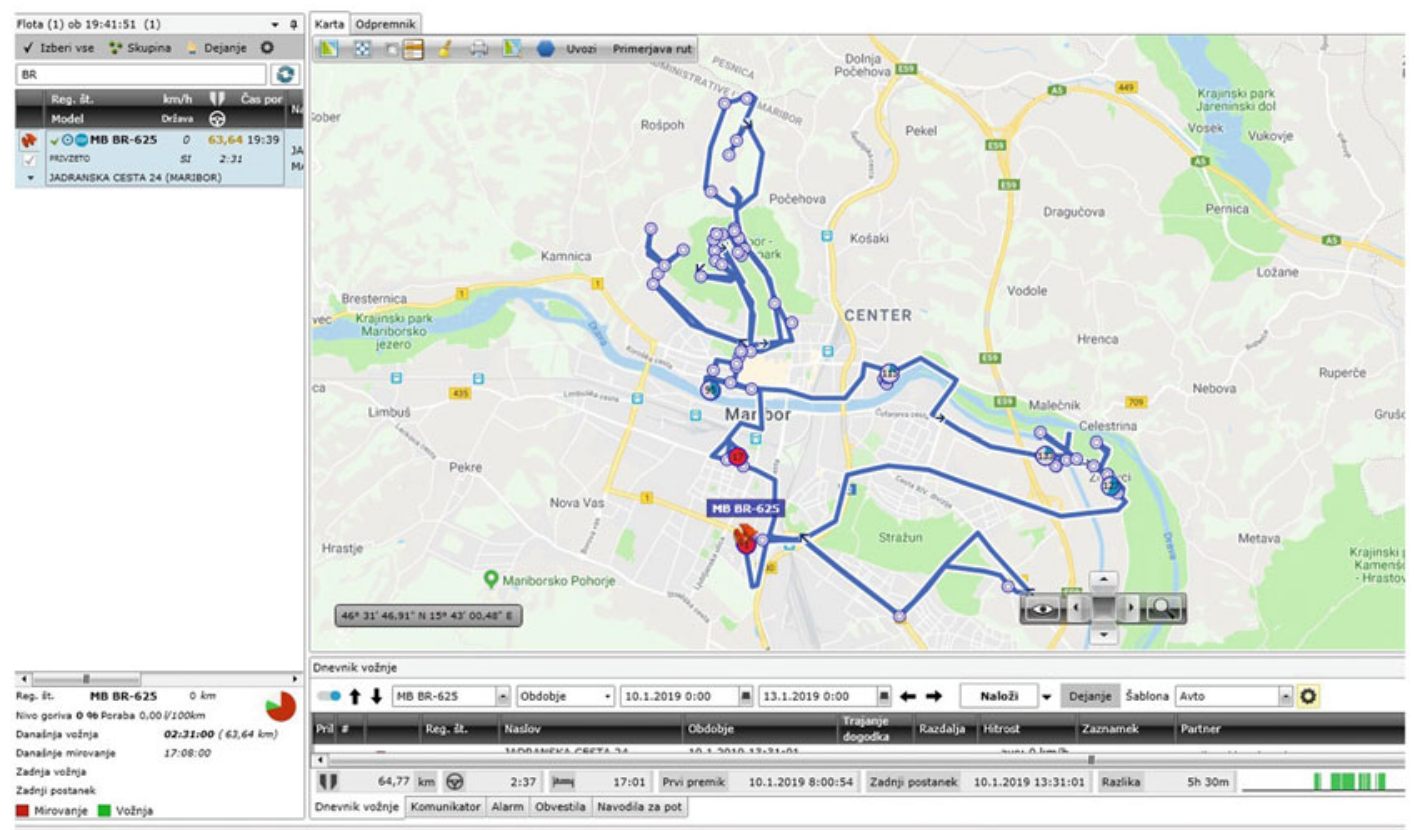

Fig. 12.11 Visualisation of the daily route of the employee collecting data from smart meters driving in his vehicle. (Source: Authors)

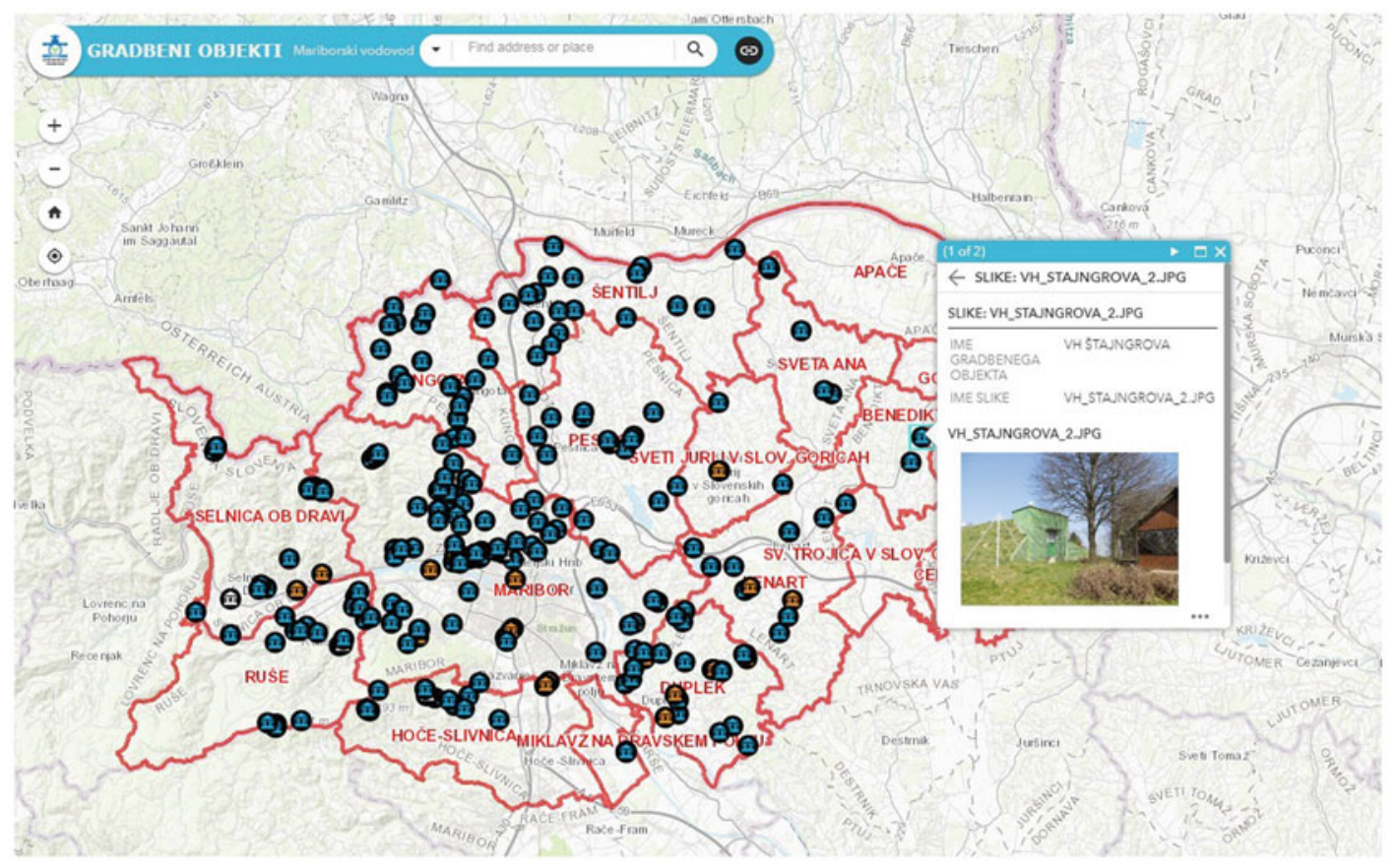

Fig. 12.12 On-line map of pumping facilities allows a comprehensive overview of the maintenance of facilities. (Source: Authors) 
Fig. 12.13 Functionality of water analytics. (Source: Authors)

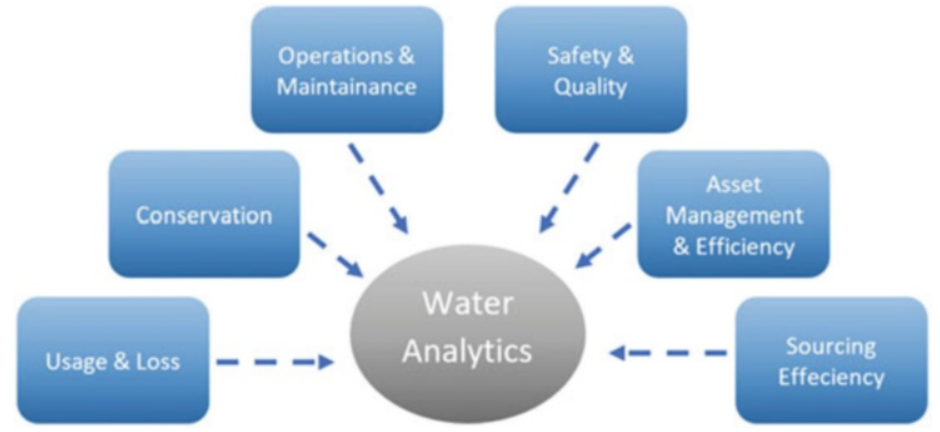

optimization of the water system and its operation what leads to less water losses and less electricity use. Hydraulic water model is visualized as shown in Fig. 12.14.

\subsubsection{Project »Mobile Spatial Data for Employees«}

For field staff real-time and up-to-date data is crucial for their work. Mariborski vodovod is using mobile devices and technology to collect data from smart water meters and for maintenance work. ArcGIS ESRI enables the use of cadastre data and maps on the field locations. Employees can upload geo-located photos to document events and conditions related to water system s shown on Fig. 12.15.

\subsubsection{Project "Satellite Water Leak Detection «}

As mentioned water system of Mariborski vodovod consist of $1600 \mathrm{~km}$ of pipelines, Pipelines are of different materials and also different age, so the condition of it is different from location to location. Such complex systems require continuous monitoring and repairs. Spots of extensive leaking can be easily detected while it is seen and therefore can be repaired. More problematic are small leaking which happens underneath and which cannot be seen. Because of pipeline beaks, up to $30 \%$ of water is lost.
Pipeline breaks are detected by metering devices which show consumption in different parts of the water system and increase shows that a pipeline break has happened. Field staff is using special detector devices which allow them to trace breaking spots. Because of the water systems complexity, it is impossible to monitor in such a way the whole watering systems by filed force.

To improve monitoring of water system, Mariborski vodovod implemented satellite detecting of water loses. Satellite scans the area using remote sensing and detects humidity up to $3 \mathrm{~m}$ below surface. Collected data are then analysed using the maps of water systems and with computer, algorithms showing possible places of pipeline leaking. The potential leaking spot is detected in the circle of $45 \mathrm{~m}$.

Mariborski vodovod got the data based on satellite remote sensing in December 2019 and analysis of collected data to show 114 places with big certainty of pipeline leaking. As shown in Fig. 12.16 the software predicted pealing on a certain street and filed staff find a break in the pipeline there after a few minutes search (Fig. 12.16).

\subsection{Conclusion}

Use of GIS in organisations and its integration with other information system becomes widespread and is an important issue for organisations. The functionality of GIS is very useful and add value to information systems already used in 


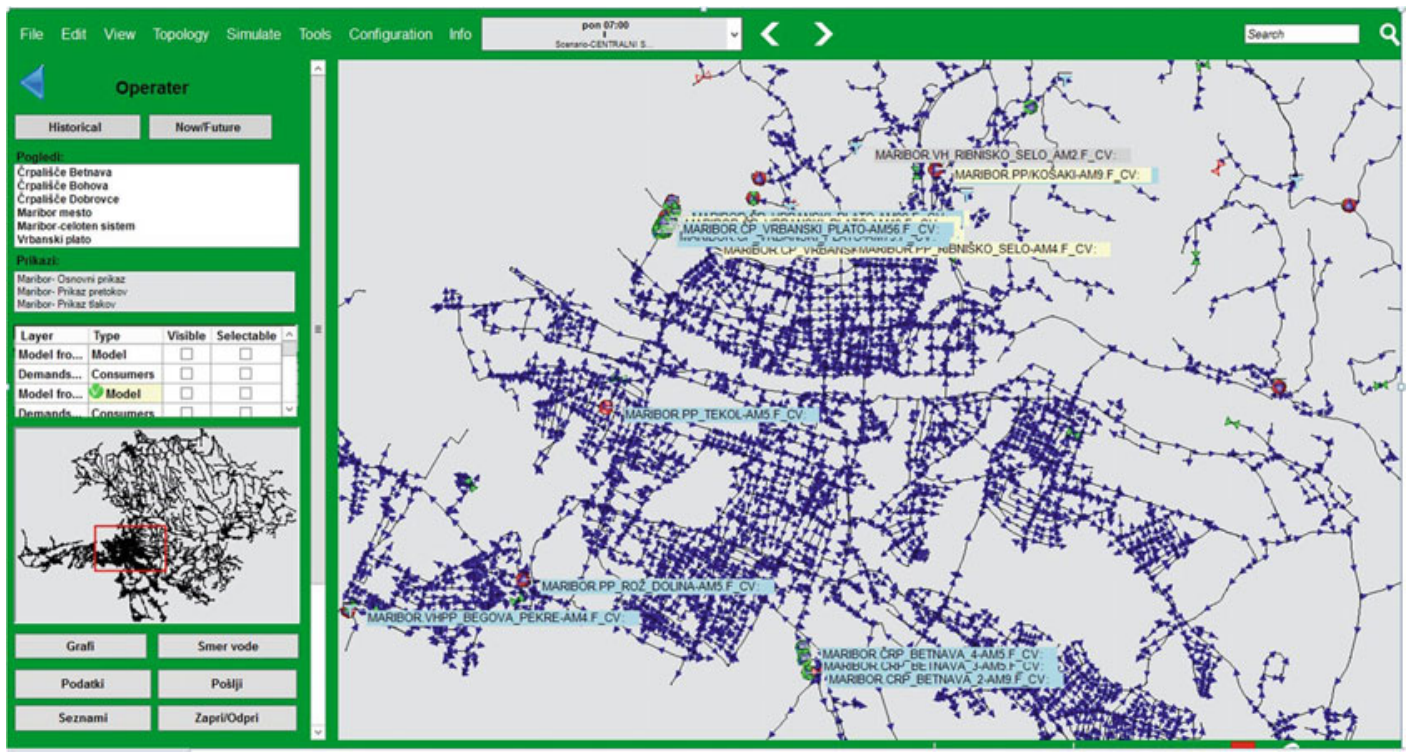

Fig. 12.14 Spatial visualisation of hydraulic water model showing water flows. (Source: Authors)
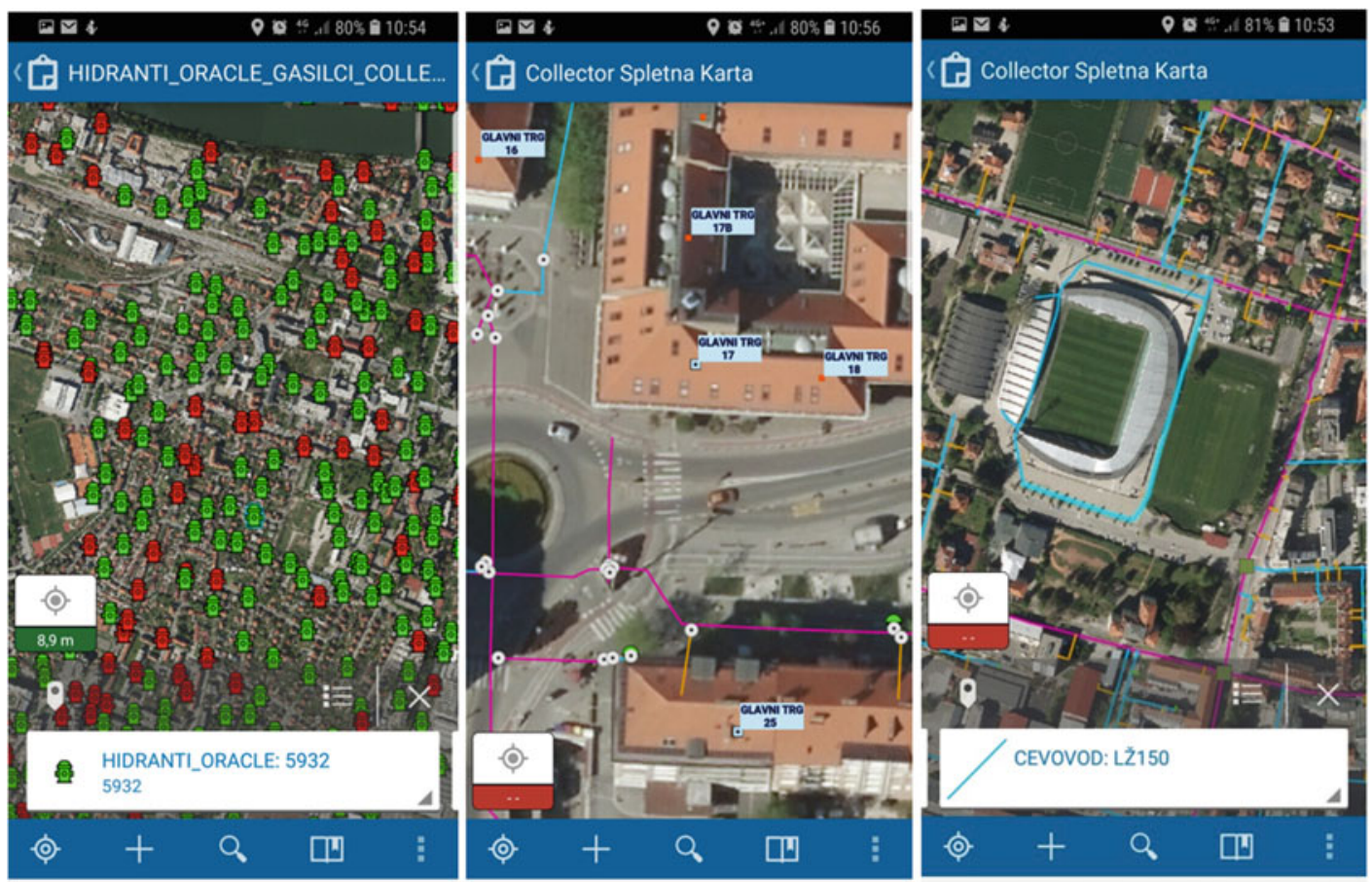

- $\rightleftharpoons \quad \leftarrow$

Fig. 12.15 Spatial data related to water system on mobile devices. (Source: Authors) 


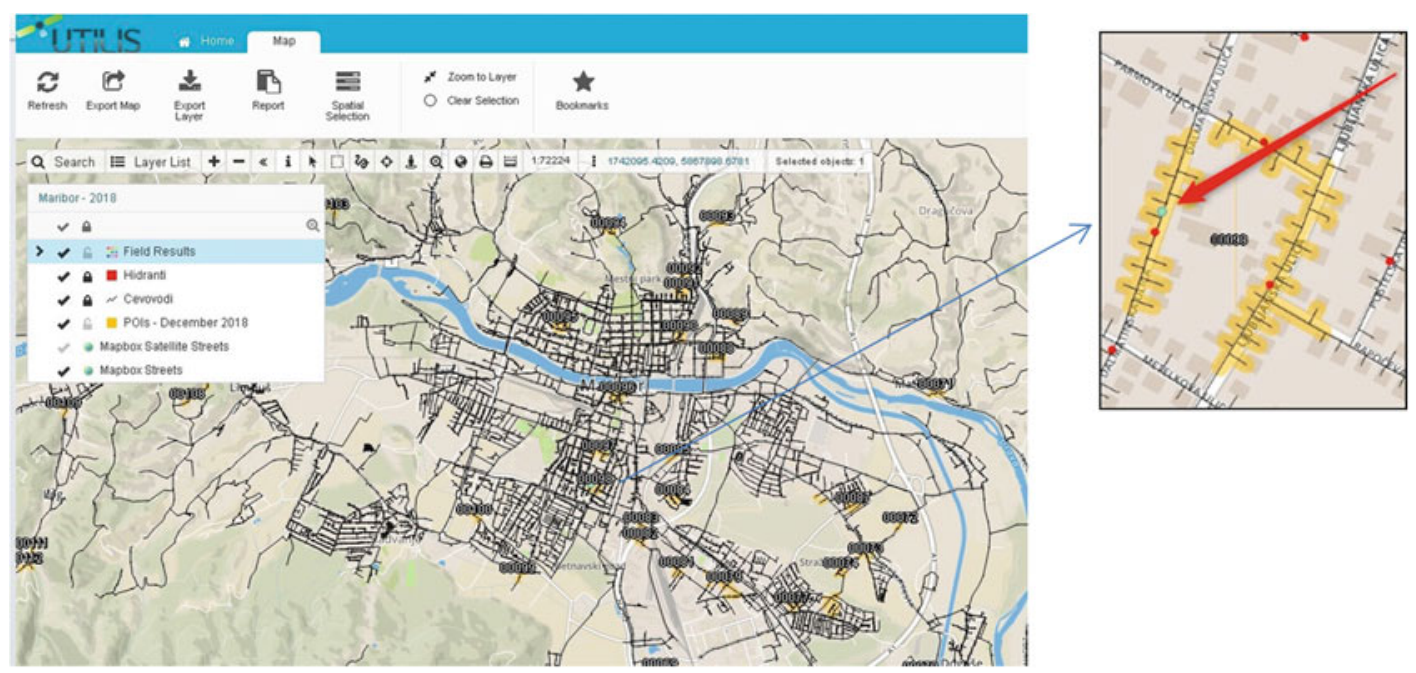

Fig. 12.16 Spatial visualisation of potential pipeline breakpoints based on satellite sensing data and computer algorithms. (Source: Authors)

organisations. Importance of GIS differs from organisation to organization and also from industry to industry. Industries with location based resources and wit location based business events are leaders in GIS implementation and use. There are many opportunities to use GIS in organizations - the company Mariborski vododovod already exploited many of them successfully Examples of GIS use in Mariborski
Vodovod show that they are beyond initial GIS use on a basic level and that they use GIS on an advanced level. According to this, we can conclude that they already entered the GIS adoption phase which correspond to stabile and advanced use and that they are approaching maturity phase. Without the leadership of top management - CEO and CIO - this could not be possible.

Open Access This chapter is licensed under the terms of the Creative Commons Attribution 4.0 International License (http://creativecommons.org/licenses/by/4.0/), which permits use, sharing, adaptation, distribution and reproduction in any medium or format, as long as you give appropriate credit to the original author(s) and the source, provide a link to the Creative Commons licence and indicate if changes were made.

The images or other third party material in this chapter are included in the chapter's Creative Commons licence, unless indicated otherwise in a credit line to the material. If material is not included in the chapter's Creative Commons licence and your intended use is not permitted by statutory regulation or exceeds the permitted use, you will need to obtain permission directly from the copyright holder. 